DIGITAL COMMONS
@ UNIVERSITY OF SOUTH FLORIDA

Volume 1

Issue 1 Volume 1 (2011): Women's Poetry

\section{ABO: Interactive Journal for \\ Women in the Arts, $1640-1830$}

Article 5

2011

\title{
"Calmly to heav'n submit your cause": Jane Cave Winscom and the Bristol Bridge Riots of 1793
}

Catherine Ingrassia

Virginia Commonwealth University, cingrass@vcu.edu

Follow this and additional works at: https://digitalcommons.usf.edu/abo

Part of the Dramatic Literature, Criticism and Theory Commons, Educational Methods Commons, Feminist, Gender, and Sexuality Studies Commons, and the Literature in English, British Isles Commons

\section{Recommended Citation}

Ingrassia, Catherine (2011) "'Calmly to heav'n submit your cause": Jane Cave Winscom and the Bristol Bridge Riots of 1793," ABO: Interactive Journal for Women in the Arts, 1640-1830: Vol.1: Iss.1, Article 5. http://dx.doi.org/10.5038/2157-7129.1.1.4

Available at: https://digitalcommons.usf.edu/abo/vol1/iss1/5

This Scholarship is brought to you for free and open access by Digital Commons @ University of South Florida. It has been accepted for inclusion in ABO: Interactive Journal for Women in the Arts, 1640-1830 by an authorized administrator of Digital Commons @ University of South Florida. For more information, please contact digitalcommons@usf.edu. 
"Calmly to heav'n submit your cause": Jane Cave Winscom and the Bristol Bridge Riots of 1793

\section{Keywords}

1790s, Bristol, Jane Winscom, occasional poems, violence, women's poetry

Creative Commons License

(c) $($ ) $\Theta$

This work is licensed under a Creative Commons Attribution-No Derivative Works 3.0 License. 
On September 30, 1793 at about 8:15 p.m., the Herefordshire militia fired into a crowd of unarmed people gathered on and near the Bristol Bridge, the only one that spanned the River Avon in Bristol in the west of England. Accounts at the time report that without reading the Riot Act or ordering the crowd near the bridge to disperse, the militia fired "directly up High-Street" upon what John Rose described as "that gaping populace," killing eleven and wounding fortyfive men, women, and children (12). ${ }^{1}$ The episode, often referred to as the Bristol Bridge Riot, was, in the words of Philip D. Jones, "one of the most serious riots, in terms of killed and injured, to occur in Britain during the last half of the eighteenth century" (74). Three of the wounded died within five days, and many of the injured subsequently had limbs amputated. The event was the culmination of two days of protest over the reinstating of the toll required to cross the Bristol Bridge which the Bridge Commission had discontinued only nine days earlier. This decision incited unrest among a range of Bristol citizens. "It is not only the lower class of people that is against the continuation of this Toll, after the Bridge is paid for," the London Sun noted, "but the inhabitants in general" (3). The atmosphere of unrest continued after the shootings as citizens broke windows in the guildhall and the council house, and threatened individual members of the Herefordshire militia with revenge.

The startling event, which was also reported in the London papers, incited extensive and highly varied commentary for weeks following the incident. Pamphlets, poems, ballads, and broadsheets circulated as well as commentaries in the Bristol's seven weekly newspapers. Unarmed British citizens shot on British soil by British soldiers aroused strong reactions_-both from those defending the actions of the militia against the "mob" and those arguing for the innocence of the victims. A handbill from the time, Plain Truth, notes that "No Citizen has been shot by a Soldier since the Days of OLIVER CROMWELL, till the late drunken and violent Massacre, committed on an unarmed Multitude” (1). At the core of these discussions were fundamental questions of authority: Who can lawfully regulate citizens' movement? What is the extent of citizens' rights to peaceful gathering? Who can command a militia to use force? These questions inform not only reactions to the Bristol Bridge episode but also two oppressive cultural practices regularly witnessed by Bristolians, steeped in a culture of violence: slavery and impressment.

Poet and relatively new Bristol resident Jane Cave Winscom (1754?-1813) published a response to the Bristol Bridge shootings with her poem, "Thoughts Occasioned by the Proceedings on Bristol-Bridge, and the Melancholy Consequences, on the Awful Night of Monday Last, Being the $30^{\text {th }}$ of September." Published anonymously, "by a Lady," the poem was sold within a week of the event. A revised version of the poem then appeared in the fourth edition of Winscom's Poems on Various Subjects, Entertaining, Elegiac, and Religious (1794). In that volume "Thoughts Occasioned by Proceedings on Bristol-Bridge” follows another 1793 poem, “An Address to the Inhabitants of Bristol, Occasioned by the Present Calamities and Recent Observations.” Together the poems interrogate the specific moment of the Bristol Bridge riot and vividly allude to the underlying challenges to Bristol's moral climate wrought by slavery and impressments. Read in the context of Bristol in the 1790s, the poems offer a sustained exploration of the tensions between individual rights and the uses of governmental authority. They address threats to liberty and the oppression of Bristol's marginalized, disenfranchised, or enslaved persons. As such, they offer insight into Winscom, a heretofore little discussed poet, into "the popular experiences and perceptions" of the riot itself (Harrison 559), and into the 
cultural tensions affecting Bristol and arguably the British nation. They also provide a powerful example of the ways female poets of the 1790s engaged issues in the public sphere in complex and subtle ways.

\section{I. “The Second City in England": Bristol in the 1790s}

Born around 1754 in Wales to exciseman John Cave and his wife, Jane Cave lived in a variety of places including Bath and Winchester before publishing by subscription her first volume of poetry Poems on Various Subjects, Entertaining, Elegiac and Religious in 1783; it was published in Winchester and listed more than 2000 subscribers from towns throughout southwest England. That 1783 collection, which went into four subsequent, revised editions, offered primarily occasional and religious verse. ${ }^{2}$ The year the volume initially appeared, Cave married Thomas Winscom, also an exciseman. Her role as the daughter and then wife of an exciseman may have informed her perspective on class and governmental authority. Excisemen collect excise duties, what Samuel Johnson describes as "a hateful tax levied upon commodities, and adjudged not by the common judges of property, but wretches hired by those to whom excise is paid” (def. 1). Excisemen pursued a relatively well-paid profession with great potential. "With the possible exception of officers of the armed forces," notes Graham Smith, "it would be difficult to find a trade or profession with salary or prospects comparable with Excise” (qtd. in Messem 8). Nevertheless, the nature of the exciseman's work was generally unpopular and, at times, hazardous. Excisemen were also required to move regularly, and every four years Winscom and her husband relocated, arriving in Bristol in 1792. ${ }^{3}$

The Bristol in which Winscom arrived was an active port city of nearly 60,000 people which characterized itself as "the second City in England" (Shiercliff 1). Bristol's period of dominance as a port had passed, although it was still an important center for both domestic and international trade. Because of Bristol's involvement in sea trade, by one estimate nearly twenty-five percent of the male working population was involved in some employment related to shipping, ${ }^{4} \mathrm{a}$ population desirable (and susceptible) to a press-gang. Consequently, early in the century, Bristol was a popular location for press-gangs seeking to force men into naval service. Press-gangs often met great resistance and Nicholas Rogers details how "cuts, bruises, and fractures were commonplace in these affrays, and sometimes gangers and their prey lost eyes, ears, and even parts of their noses” (13). Bristol was notorious for its fierce resistance to the efforts of pressgangs. For example, in 1759, Admiral Gordon's press-gang was “assailed with 'vollies of small shot'" in which one sailor was killed and several members of the press-gang were wounded. This episode, indicative of press-gang encounters in the 1750s, stopped press-gang activity in Bristol for a while, although "the memory of the bloody confrontations... were seared into the consciousness of the gangs" and doubtless the general population (Rogers 78-79). ${ }^{5}$ The strong reaction to press-gangs was consistent with other kinds of social unrest that occurred in Bristol. In the early part of the eighteenth century, the city experienced at least eleven episodes of civil disturbances between 1709 and 1753, and as Mark Harrison notes, "the reputation of the South West for riot remained well justified during the second half of the eighteenth century” (559).

Bristol's port and geographic location in the west of England made it an integral player in the "triangular trade"-Britain, West Africa, and the West Indies-from the earliest part of the century, and, as Linda Colley notes, the economy "rested heavily on overseas trade with North 
America and the West Indies” (84). Bristol's involvement in the slave trade "had greatly diminished by 1793” (Morgan 221), eclipsed by that of Liverpool's, yet during the 1790s ships originating in Bristol still consistently proceeded to West Africa and transported enslaved Africans to the West Indies; in 1793 alone, ships originating in Bristol transported 9,110 Africans (Voyages). In fact, Thomas Clarkson (1760-1846), who worked closely with William Wilberforce (1759-1833) in the parliamentary anti-slavery campaign, drew heavily on Bristol in providing examples of the moral and physical dangers of the slave trade. In service of the committee for the abolition of the slave trade, Clarkson, in 1787, took responsibility for investigating every source of information relevant to their cause. After completing his research in London, he moved on to Bristol. The resulting document, The Substance of the Evidence of Sundry Persons on the Slave-Trade (1788), like his widely distributed An Essay on the Impolicy of the African Slave Trade (1788), reveals that while Bristol's involvement had diminished, the cultural legacy remained very much in place. His report is filled with interviews with Bristol men involved in the trade as captains, merchants, or sailors; it also details the treatment of seamen and enslaved Africans. Bristol was "particularly" notorious for crimping, or entrapping, men into service: "there are certain landlords, who make a practice of crimping seamen for the slave trade. They suffer them to run into debt from a prospect of the advance money that will be given them, and then consign them to vessels" (66-67). ${ }^{6}$

Bristol also retained an association with slavery through its dominance in the sugar trade. The Bristol and Hotwell Guide accurately claims "there is more sugar imported into Bristol from the West India islands, in proportion, than there is even into London" (Shiercliff 18). ${ }^{7}$ Sugar, as many scholars have discussed, is considered a "slave commodity." "Sugar seems to result from the physical excretions of the slave-tears and sweat," writes Charlotte Sussman, as well as "his or her agricultural labor;" in abolitionist rhetoric of the period there is "the equation between the slave's body and the sugar it produces” $(53,55)$. In Bristol, the port traffic from the West Indies bearing primarily raw sugar for refining in Bristol sugar houses was considerable. The week of the Bristol Bridge riot, the shipping news in The World notes that on September 30, the Leeward Island Fleet returned to Bristol with nine ships arriving from Nevis, St. Kitts, Barbados, and Antigua (4). Similarly, Lloyd's List from Friday October 4, 1793 details twelve ships docking in Bristol, eleven from Jamaica and one from Antigua (2). It is also reasonable to assume a visible population of Africans in Bristol.

While 1793 was a prosperous time for Bristol's wealthy sugar magnates, who would not cede dominance in the sugar trade to Liverpool until 1799, not all shared the financial benefits. The price of consumer goods rose precipitously between 1789 and 1795. War with France was declared in February 1793 leading to a steep decline in the building trade which, in turn, contributed to rising unemployment. Bristol had 94 bankruptcies in 1793, compared with 13 in 1792, and the Bristol economy was experiencing what Winscom describes in "An Address to the Inhabitants of Bristol" as "numerous Bankruptcies and other Calamities" (Poems 173); "If those who late soft affluence could boast,” writes Winscom, “A scanty pittance now possess at most!” (ll. 5-6). Additionally, Bristol was governed by a corporation, also responsible for the Bristol Bridge, that engendered limited respect—or, as Harrison asserts, "long-held dislike"—from its citizens (561). These local tensions, coupled with growing national anxiety about social unrest exacerbated by the American War and the French Revolution, ${ }^{8}$ created a volatile situation. 
Rebuilt in 1769, the Bristol Bridge itself was financed in part by a toll that was to be collected only until a $£ 2000$ surplus existed; then interest on the $£ 2000$ was to pay for bridge maintenance. The Bridge Commission, part of the governing body of Bristol, announced tolls would end September 19, 1793; on that date the gates were removed and no tolls were collected. However, four days later, the bridge commissioners, without publishing their accounts, publicly denied they had sufficient funds and then, after nine toll-free days, erected new toll gates on Saturday September 28. The first citizens' protest occurred that day as people gathered at the toll house protesting the reinstatement of the toll. Jones notes that the "... protestors believed that the bridge commissioners were acting illegally, as well as deceptively, when they did not end the tolls... and that crowd action was thereby justified" (84). ${ }^{9}$ The Riot Act $^{10}$ was read and, according to an account published shortly after the incident, "the magistrates sent for the military, to awe the people into submission” (Rose 8). ${ }^{11}$

The arrival of the militia with its fife and drum had the effect of attracting individuals to the location rather than driving them away. At 11:30 p.m., the militia fired a warning shot to disperse the crowd; it killed John Abbot, a builder's laborer who happened to pass by the crowd on his way home from a pub. The next day, Sunday September 29, the militia was still present, and while a few altercations occurred on the bridge- and the chanting of 'No toll, no toll' - the militia was not ordered into action. The Riot Act was again "read . . to very little purpose, tho' the crowd was by no means so great as might have been expected, considering the force of curiosity, the greatness of the thoroughfare, and its being Sunday” (Rose 9). 2,000 Handbills were printed and distributed, stating that the Riot Act had been read and warning people to stay away from the bridge on that day with details that the military were to fire in case of "any tumult."

Monday morning, September 30, a chain hung across the bridge (for the toll gates had been burned by the crowd the previous Saturday), halting the flow of all traffic across the bridge. John Rose notes that "the average number of persons who pass over Bristol Bridge in a minute is more than sixty . . . every interruption, even of a few minutes, must therefore make a crowd" (11). Between 10:30 and 11 a.m., the Riot Act was read three times to the crowd that gathered, yet the arrival of the militia brought no forcible efforts to disperse them. Five hundred handbills with that day's date were printed, but it is not clear they were actually distributed. "The people who were looking on,” writes John Rose, “and many of those who passed by, crying, Go on! No toll! With such a variety of hissing, huzzaing, and clamorous noises, as frequently startled the horses" (10). Despite obvious tensions with the crowd, the magistrates, constables, and soldiers all left the bridge between 6 and 7 p.m. More than one account describes the soldiers as "quite drunk" because others "gave unto them much Liquor” (Lamentation of Bristolia 7).

Shortly thereafter a group from the crowd made a bonfire, to which they added "the table, chairs, and what else was combustible, even the door" from the toll-house itself (Rose 12). The bonfire prompted the return of the militia and officials to the bridge at about eight. The reportedly carnival atmosphere of the previous days had increased the number of spectators: "There were some [not the most prudent] who had children upon their shoulders, to 'see the sight!'” (Rose 12). Pelted by oyster-shells and stones thrown by the crowd, the militia were ordered to shoot and 
the front rank fired upon their assailants and the gaping populace: some oyster shells being that instance thrown from that part of the Back near St. Nicholaschurch, the rear faced about, and fired directly up High-street. Men, women, and children, flew on all sides: and whilst the press which it occasioned impeded the progress of their flight, it gave the military an opportunity to practice the science of street-firing with astonishing adroitness, the people being brought down by the musquetry in almost every direction. (Rose 12)

Some accounts report that individual soldiers picked off stragglers as though "trying their skill at a flying shot" (Rose 12). Others claimed that the soldiers were ordered to "FIRE LOW: spare neither Age nor Sex" (Lamentation of Bristolia 7) According to another account, "[t]he angry soldiers . . . left their ranks in order to single out individuals, whilst others of them kept a desultory fire up every street that radiated from the bridge” (Nicholls and Taylor 3:218). A handbill, The Extraordinary Gazette, published a satiric representation of the event, "Extract of a Letter from General Don Diego Twig Pigeon, to His Satanic Majesty,” which labels the populace the "enemy;"

The Enemy received us with a Volley of Brick Bars, and Oyster Shells (they not being provided with other Weapons) which we immediately answered by a heavy Fire of Musquetry ... Mistaking a Number of the Inhabitants who appeared in our Rear, (brought together by the sound of the Drum) for a Part of the Enemy, we ordered our Soldiers to face about and Fire; the Consequence was, many peaceable Inhabitants of the City of Bristol fell, amongst whom were some Women and Children. (1)

The attack had a leveling effect and the victims represented a cross-section of Bristol's society, a cause of both despair and further anxiety. The London World reported that "a Midshipman belonging to the press-gang has been wounded, and it is feared, from this unlucky circumstance, that the sailors will join the rioters, who have already proposed to release the prisoners, that their numbers may be strengthened" (3). Fears of escalating violence persisted among a populace with eleven dead, forty-five injured, and a damaged attitude toward Bristol's authorities.

\section{II. “My Pensive Muse”: The Politics of Winscom’s Reflective Poetics}

Prior to her published response to the Bristol Bridge Riots, Winscom's engagement with issues in the public sphere was certainly present but not overt; however, over the course of her career she evinced a heightened sense of agency and an increasing awareness of, in the words of Clifford Siskin, "writing's capacity to produce . . change” (3). Strategic revisions in the five editions of Poems on Various Subjectspublished between 1783 and 1795 increase the political resonance of Winscom's poems. The first three editions contain poems that center on the questions of authority, national identity, and morality similar to those that inform her reaction to the Bristol Bridge Riot. In those early editions, however, their political nature is obscured somewhat by generic, non-specific titles or classification with poems "On Religious Subjects." In later editions, subtle adjustments heighten the poems' political focus and Winscom's claims for agency as a poet. For example, a "Poem Occasioned by Hearing Prophane Cursing and Swearing” (1783) gains new meaning when "at the Time of the American War" is added to the 
title in 1786. ${ }^{12}$ ) “On the General Fast, Feb. 8 1782” beseeches God “Our land, our sinking land protect" (33); when positioned as the final poem in the volume in 1789, it assumes a powerful, valedictory tone.

The most overtly political poem in the 1783 Poems on Various Subjects, "Written by the Desire of a Lady, on Building of Castles,” criticizes Britain's involvement in the American War by questioning governmental authority and decisions that led to costly military encounters. ${ }^{13}$ The original title belies the content. However, when the phrase "During the American War" is added, the poem's active critique of British foreign policy is foregrounded. The poem begins with a description of the original use of castles constructed in the material world: "for our defence, / And usually erected were, / Adjacent to the Seat of war" (2-4). While "blood and slaughter did abound" (5), the castles, decorated by the "whole artillery of war" (16), serve to defend against the enemy. If these physical castles can be justified, the castles "fabricated in the air / . . the mental kind, / The sole construction of the mind" cannot (22-24). Such a castle "Our ministry . . . built" when it "Fancy'd a thousand men or two / Could all AMERICA subdue" (31, 33-34) Winscom vividly describes the human cost to the British nation attempting to retain control of America:

But thrice ten thousand cross'd the main, A million's in the contest slain.

Yet, ah! Fell castle, direful ill, AMERICA's un-conqu'red still. $(35-38)^{14}$

While it would be an overstatement to describe Winscom as radicalized or even increasingly liberal in her views, these kinds of revisions evince a more assertive tone that demands reflection from the reader. The two volumes published in the 1790s (1794 and 1795) after Winscom's arrival in Bristol give voice to her support of abolition, her condemnation of British foreign policy, and her (limited) sense of empowerment through her published work. Her poetic response to the Bristol Bridge Riot a decade later illustrates Kathleen Wilson's observation that "far from being expelled from the new public culture of the period, women, it seems, were pivotal creators and participants in it” (92). Within this context of heightened political awareness, we can read her poem on the Bristol Bridge.

Winscom published “Thoughts Occasioned by the Proceedings on the Bristol Bridge” immediately after the episode, and then revised the poem for inclusion in the 1794 edition of Poems on Various Subjects. In the version published within a week of the events on the bridge, the title notes the date as "the Awful Night of Monday Last, Being the $30^{\text {th }}$ of September, 1793" (Image One). It was published anonymously, written "by a Lady," and sold for three pence. The poem recounts the events of the night of the shooting, offering the perspective of both the innocent victims and the militia; most notably, it rejects all justifications for retribution or vigilantism, advocating instead a faith in divine justice. Written in the conditional voice, the poem likens the situation at the Bristol Bridge to the Biblical city of Sodom. When Lot asked "Ah! Wilt thou not the city spare / If fifty righteous souls are there?” (42-43), "the great I AM" (51) (Jesus) was "cautious" allowing Lot and his family to escape. The magistrates at the Bristol Bridge have not acted with such "conscience;" in their zeal to restore order, they, in the metaphor of the body politic, have "cure[d] the swelling of the toe, / By the whole body's overthrow" (76- 
77). Winscom advises instead a return to "The Book we call our rule of life," the Bible, which "promotes no bloodshed, noise, or strife" (94-95).

The different opening stanzas of this poem mark their proximity to the event. The 1793 version, (Image One), published within a week of the shooting and designed to quell citizen unrest, begins with an epigraph from Matthew 8.29: "But He said, nay, lest while ye gather up the Tares, ye root up also the Wheat with them” ("Thoughts” 1). If one of the central questions of the events on Bristol Bridge was who had the authority to order the militia to fire, Winscom points to a higher authority - “the great incarnate Lord” (l. 1). Winscom uses the designations of local magistrates to refer to God who is figured as "CAPTAIN of all the Hosts on high" and "Chief MAGISTRATE of Earth and Sky” (3-4). That verbal move diminishes the corporation's local, ultimately limited authority. Had God been in command, asserts Winscom, "Carnage and Woe had not prevail'd, / Not Horror ev'ry Face assail'd” (7-8). As the first stanza concludes, it captures the confusion and movement of the episode:

While Bullets flew from Street to Street, Leaving no Moment for Retreat;

But winging through the Smoke and Fire, Made Numbers groan ! bleed! And expire! (9-12)

The term "retreat" echoes the adversarial tone used by the Bristol's officials, in which the citizens are the "enemy," while the last two lines-not included in the revised 1794 version of the poem-present the progressive suffering of both the individual and the collective: "groan," "bleed," and "expire." With the last line of the first stanza, Winscom actually modifies a line that appeared in the first stanza of "Written by the Desire of a Lady, On Building of Castles": "Made thousands groan, bleed, and expire” (10). Doubtless that mild 'self-plagiarism' prompted her to remove the line from the poem when it appeared in the same volume as "On Building of Castles." While the poem ultimately advocates patience in the face of a desire for retribution, the rhetoric of this opening stanza uses more inflammatory language perhaps because of its publication within days of the event.

By contrast, the 1794 version of the poem that appears in Poems on Various Subjects has a new, additional, opening stanza that may invite a more reflective reading. The poem, within the volume, follows "An Address to the Inhabitants of Bristol, Occasioned by the Present Calamities and Recent Observations,"* which also responds to events in Bristol. Winscom's footnote qualifies the title of that poem: "*Written in the Year 1793, in Consequence of the numerous Bankruptcies and other Calamities that occurred there at that Period" (Poems 173). While the number of Bristol bankruptcies did increase in 1793, the "other calamities" clearly include the Bristol Bridge riot. "An Address to the Inhabitants of Bristol” begins by asking the citizen to "pause" and reflect on "the sins our house conceals" that cause "ruin and distrust [to] pervade our streets;" "... sins of deepest die infect the place, / And sink the Man below the brutal race" $(1,11,3,9-10)$. Winscom details episodes of cruelty to animals that happen on the streets of Bristol: The horse which is beaten to death, when "lash succeeding lash his body wales" (30); the "Dogs, cats and pigs, the harmless bird and fly,/ Live to be tortur'd, or by tortures die!" (4748). These "horrid scenes"15 (49) embody the real subject of her poem—“* The SLAVE TRADE” (Poems, 1794 177). Winscom does not use that term within the poem; she includes it 
only as a footnote where, visually it is set apart, centered at the bottom of the page. Just as "numbers pass by and view each horrid scene" (51) of cruelty to animals without comment, so too all citizens of Bristol by silence make the guilt of slavery their own:

To cruelty inur'd we think that just

Which should excite abhorrence and disgust;

And thus inur'd we send our ships abroad,

To buy and sell, and sport with HUMAN BLOOD! (55-58)

The repeated use of the term “inured” captures the essence of Winscom's poem; Bristolians, accustomed to seeing the operations of the slave trade, do not reflect upon a moral climate in which the Bristol Bridge episode seems, perhaps, inevitable.

"Thoughts Occasioned by the Proceedings on Bristol-Bridge" follows that poem, suggesting Winscom may have assumed (or hoped for) a linear reading of the volume (or at least a sequential reading of the two poems). It begins: "PAUSE, reader!" This opening injunction compels the reader to reflect upon the previous poem, depicting a desensitized public. Winscom may also want the reader to consider the multiple discourses contained in the first page of the poem (Image Two). The use of the term "Thoughts” in the title (rather than "An Address") retains the occasional quality of the poem's initial composition. The slightly revised title places the event in the past, and the subtitle offers something akin to a journalistic description of the event: "the Awful Night of Monday, the $30^{\text {th }}$ of September, 1793, When the Military were ordered to fire on the Populace, in Consequence of their collection together, to obstruct the Continuance of the Bridge Tolls, by which Means many innocent People passing by lost their Lives” (Poems, 1794 181). The term “awful night” suggests, perhaps, a slightly Gothic tone, while the placement of the quotation from Matthew, previously an epigraph, at the bottom of the page as a footnote gives the page the appearance of a scholarly text. These diverse generic elements-journalism, fiction, scholarship and, of course, poetry (as we are reminded by the header at the top of the page) - provide a complex and perhaps more visually confusing point of entry to the poem than the 1793 version.

The prose subtitle captures the poem's fundamental tension between Winscom's call for civil authority and her critique of state violence. Her use of the term "proceedings" carefully avoids the suggestion of a riot, yet the term "populace," while distinct from "mob," possesses a similarly derogatory connotation. That populace "obstructed" the tolls with the inevitable "consequence” of the militia’s assault. Citizens who defy civil authority will potentially suffer sanctioned retribution. Winscom neither defends nor denounces the Herefordshire militia, but notes their lack of agency_ “the Military were ordered to fire.”

Winscom highlights the ways in which state violence can too easily affect law-abiding citizens who adhere to the dictates of public order. Because of the nature of the militia's assault, firing into a crowd, readers too could easily have been victims, for

Thy husband, neighbour, friend, or son

All tranquil stood as thou hast done: 
When lo! they met the awful doom!

Which now consigns them to the tomb. (“Thoughts,” Poems 3-6)

Events could have been avoided with "the MAGISTRATE on high" (7) in command, with divine guidance.

The honest tradesman homeward bound,

Would not have met the mortal wound;

No amputated legs or arms,

(As tho' amid dire war's alarms)

The hapless woman, boy, or man,

Had mourn'd through life’s protracted span. (“Thoughts,” Poems 13-14, 17-20)

Instead, victims will bear the scars of a kind of domestic war whereby "amputated legs or arms" remain permanent cultural reminders. Her detailed descriptions of the unnamed victims are consistent with John Rose's "list of the wounded; with their ages, descriptions of their Wounds, \&c.” published in An Impartial History of the Late Disturbances in Bristol.

Once initiated, authorized violence against citizens cannot always be contained, potentially affecting even those most committed to the doctrines of control within civil society. Winscom describes the imagined death of her own husband - "He ! who with warmth espous'd the cause/ Of those who sought t'inforce the laws," "Had [he] pass'd the street in duty's call," "he! with ball in breast or head, / Perchance had sunk among the dead! ("Thoughts," Poems 29-30, 25, 3839). By imagining an exciseman such as her husband as a possible victim, Winscom highlights the consequences of broadly applied authority, when a militia "fire promiscuously on all" ("Thoughts," Poems 46). She also focuses on the excessive nature of the act, consistent with accounts that describe how victims were shot fleeing and some militia broke into individuals' homes: . . . bullets flew from street to street, / Leaving no moment for retreat” ("Thoughts," Poems 11-12). The poem repeats the persistent question surrounding the incident: "By whose command the bullets flew?" The question interrogates not just who, specifically, ordered the shooting but also, theoretically, who possessed the authority to order the militia to fire on a group of "spectators, and indeed the rioters" which, as John Rose describes, "had not the least idea that the military would fire ... they had no knowledge, that the [riot] act being read to others, nine hours before, was a legal warning to them” (13).

Although Winscom laments the shooting of innocent citizens, she is simultaneously attentive to the untenable situation of the militia, compelled to fire as ordered or risk charges of insubordination and the punishments that follow. The attention to the individual British soldier appears throughout this poem and Winscom's volume. "What private soldier durst withstand" asks Winscom, "His stern superior's dread command?" (84-85). The soldiers themselves are, in a sense, victimized by the military authority that controls them; they are also "grossly insulted" (Poems, 1794 186) and treated "with unjust abuse" (l. 182) by citizens of Bristol, "so great was the Resentment of the People against the Military" (Manson 49). ${ }^{16}$ One of the most vivid images in the poem is the imagined military punishment of a fictional insubordinate soldier who refuses to fire: 
... with his arms to halberds ty'd, In streaming blood had soon been dy'd, While lash succeeding lash had flown, And stript the culprit to the bone $!^{17}(88-91)$

It is notable that the most graphic image of violence in the poem is not a depiction of a shooting but the flogging of a British soldier. Winscom displaces the description of violence from the citizen to the legal authority highlighting the continuum of sanctioned state violence. The image also summons descriptions of the treatment of enslaved Africans on West Indian plantations which were widely distributed after the introduction of Wilberforce's bill to end England's involvement in the slave trade in 1790. A passage that seems to depict the plight of a British soldier more broadly engages Bristol's involvement in slave trade both through the transporting of slaves and through participation in the sugar trade; the image may, secondarily, resonate with Bristol's history of violence with press-gangs. All three situations, linked visually and structurally, undermine Britain's claim to moral authority as well as the implicit rights granted to a "free-born Briton." Domestic actions by British authorities were questioned as, at the end of the century, the emergent concern for British liberty became overwhelming,especially as the French had highlighted Britain's claims to be the land of liberty during their own revolution.

In the face of a desire for retribution by Bristol citizens, Winscom urges "forbearance! kindness! love!” for those seeking "redress," a compensation or reparation usually conferred through legal means ("Thoughts," Poems 96, 99). Within the poem, she ventriloquizes her husband's conservative views which privilege procedure over protest:

('The legal pow'r should be obey'd, And due investigations made;

If wrong, -to law apply for aid, And not by riot seek redress' ....). (“Thoughts,” Poems 31-34)

She fashions her poem as the means for deterring those seeking immediate, physical revenge: "let this Page your minds impress, / Who by revenge would seek redress; / For limbs or friends that's torn away" (98-100). She, again, urges a reflective moment among the collective "let this Page your mind impress." She does not even concede the possibility of a local, legal resolution; rather she urges citizens “Calmly to heav'n submit your cause” and trust a higher authority (103). Just as Anna Laetitia Barbauld reminds Wilberforce he will be favorably judged by "faithful History,” Winscom asserts that "vengeance belongs alone to GOD!” (106) a transcendent morality removed from the contingencies of misunderstood military orders or mediated interactions. Messem suggests that "in the tone and content" Cave "aligns herself firmly with the more humble and wage-earning ranks," although her tone seems instead to share a perspective with the middling classes (9). While her poems strategically deploy vivid images of violence to remind readers of the dangerous climate of Bristol, she advocates a course of moderation, "common sense," and reason. Winscom's conciliatory tone seeks to dissipate the perceived radicalism of the "populace" and affirms the legal and moral authority of the status quo. It is perhaps appropriate, then that The Bristol and Hotwell Guide concludes its description of Bristol by noting: "We have only further to remark, that no place in England is better regulated with 
respect to the police than Bristol” (63). Ultimately Winscom's poem endorses regulation even at the expense of individual rights.

\section{Winscom's Poetic Authority}

Winsom's poems on Bristol and the incident at the Bristol Bridge capture the fraught climate of the 1790s and the fundamental contradictions between Briton's claims for moral authority despite its involvement in ongoing violations of human rights. These two poems, like others in the volume, address basic questions of governmental authority and military authority in the face of an engaged citizenry. Who has the right to collect tolls? Who has the power to order a militia to fire on unarmed citizens? Who has the right or responsibility to read the Riot Act and when? These questions shape the poems, and even as Winscom retreats from condoning the actions of the crowd, she remains constant in her concern for consistent civil order.

These questions of local, situational authority necessarily engage similar questions at the global level, questions central to what Winscom describes as "our reformed enlighten'd day" ("Thoughts Occasioned” 63). When and to what degree should civil or military force be used against citizens? Who has the authority to impress a male citizen into naval service? What national interests justify the deployment of troops on domestic or foreign soil? What is the appropriate balance between personal liberty and national security? How can the nation continue to participate in the slave trade? Winscom addresses that final question directly in the penultimate poem in the volume, "Thoughts on the Present Times; Written Some Time after the Proclamation for the Late General Fast.” Written, as the title suggests, as a similarly occasional poem, "Thoughts on the Present Times" presents the plight of enslaved Africans as comparable to the enslaved Israelites; accordingly England's ongoing engagement in military conflicts, "when thousands undistinguish'd bleed," are like the "vengeance cloth'd in blood" delivered by God to "All who deny'd that Liberty" (9, 49, 52). Although Winscom still seeks divine interaction to break "the dire oppressive band" that "have bound . . . Afric's hapless race" (5556); she also finds hope in "Great Wilberforce-soft pity's friend” (61). Urging him to "pursue thy grand design; / Till horrid slavery shall end, / And Afric's sons with freedom shine” (62-64), Winscom expresses her hope that through his efforts, "May truth and justice sway the realm, / And each opposing voice destroy” (71-72).

Ultimately we must ask what claims for authority is Winscom making for herself as a poet? The opening poem in the 1794 edition of Poems on Various Subjects modestly describes her verse as filled with "a thousand faults and more" (2), a predictable rhetorical move. Yet the poems within that volume offer criticism of British involvement with the American War, detail her successful efforts in 1791 to raise by subscription funds to get an impoverished widow out of debtor's prison, and repeatedly critique the moral atmosphere of Bristol. These subjects suggest Winscom thought her specific and direct engagement in the public sphere would have some measured effect. Additionally, publishing “Thoughts Occasioned by Bristol Bridge” separately and then also including it, revised, in the fourth edition of Poems on Various Subjects, reveal she felt increasingly authorized to comment specifically, directly, and immediately on the situation in Bristol. Her ultimate conclusion defers to a higher authority-God-and is perhaps typical of Bristol's middling "progressives” whose radical impulses are compromised by social deference and an anxiety about social unrest. Yet her poems demonstrate the wide reaches of the subject of 
women's poetry and their unflinching treatment of some of the most pressing issues of the day. Ultimately she increasingly sought not just to function within the public sphere as a spur to social change or a voice of cultural memory; she also sought to reveal the discrepancy between the cultural ideal—the high standard demanded in the age of enlightenment—and the different cultural realities her poems present.

These Winscom poems, like many by her female contemporaries such as Barbauld, Elizabeth Teft, the Falconer sisters, or Amelia Opie (to name but a very, very few), contradict essentializing discussions that look at women's poetry as primarily autobiographical. Although often personal responses to public issues, these poets demonstrate women's deep engagement in imagining their world, and their position in it, differently. They illustrate women's awareness of the complexities of domestic and foreign policies and the implications of the same for the lives of citizens, adding a new dimension to our understanding of women's poetry and the cultural history of the time. 


\section{Works Cited}

Backscheider, Paula R. and Catherine Ingrassia. British Women Poets of the Long Eighteenth Century. Baltimore: Johns Hopkins UP, 2009. Print.

Barbauld, Anna Laetitia. Epistle to William Wilberforce, Esq. On the Rejection of the Bill for Abolishing the Slave Trade. London, 1791. Print.

Clarkson, Thomas. The Substance of the Evidence of Sundry Persons on the Slave Trade, Collected in the Course of a Tour Made in the Autumn of the Year 1788. London, 1789. Eighteenth Century Collections Online. Web. 2 Feb. 2011.

Colley, Linda. Britons: Forging the Nation 1707-1837. New Haven: Yale UP, 1992. Print.

Diego, General Don. Extraordinary Gazette, Published by Authority (Price Two Pence.) Bristol, October 2, 1793. No.1. Extract of a Letter from General Don Diego. Twig Pigeon, to His Satanic Majesty. [Bristol?], [1793?]. .Eighteenth Century Collections Online. Web. 1 Feb. 2011.

Douglas, Francis. The History of the Rebellion in 1745 and 1746, Extracted from the Scots Magazine: With an Appendix. Aberdeen, 1755. Eighteenth Century Collections Online. Web. 1 Feb. 2011.

Grundy, Isobel. “Cave, Jane (b. 1754/5, d. in or before 1813).” Oxford Dictionary of National Biography. Oxford UP, 2004. Web. 30 Jan 2011.

Harrison, Mark. “'To Raise and Dare Resentment': The Bristol Bridge Riot of 1793 ReExamined.” The Historical Journal 26.3 (1983): 557-85. Print. http://dx.doi.org/10.1017/S0018246X00021063

Johnson, Samuel. "Excise.” A Dictionary of the English Language. Vol. 1. London, 175556. Eighteenth Century Collections Online. Web. 1 Feb. 2011.

Jones, Philip D. “The Bristol Bridge Riot and Its Antecedents: Eighteenth-Century Perception of the Crowd.” Journal of British Studies 19.2 (Spring, 1980): 74-92. Print. http://dx.doi.org/10.1086/385756

The Lamentation of Bristolia: Or, the First Chapter of the Chronicles of Judas and Human. Bristol, 1793. Eighteenth Century Collections Online. Web. 1 Feb. 2011.

Lloyd's List [London]. 4 Oct. 1793: 2. 17th-18th Century Burney Collection Newspapers. Web. 30 Jan. 2011. 
Lonsdale, Roger. Eighteenth-Century Women Poets: An Oxford Anthology. New York: Oxford UP, 1990. Print.

Manson, Michael. “Riot!” The Bristol Bridge Massacre of 1793. Bristol: Past and Present, 1988. Print.

McKim, Elizabeth. "Making Poetry of Pain: The Headache Poems of Jane Cave Winscom." Literature and Medicine 24.1 (Spring 2005): 93-108. Print. http://dx.doi.org/10.1353/lm.2005.0030

Messem, Catherine. "Irreconcilable Tensions; Gender, Class and the Welsh Question in the Poetry of Jane Cave (c1754-1813)." The Welsh Writing in English; A Yearbook of Critical Essays. Vol. 2. Cardiff: U of Wales P, 1996. 1-21. Print.

Morgan, Kenneth. Bristol and the Atlantic Trade in the Eighteenth Century. Cambridge: Cambridge UP, 1993: Print.

Nicholls, J. F., and John Taylor. Bristol Past and Present. Bristol: Arrowsmith, 1881-1882. Print.

Plain Truth. About Thirty-Four Years Ago It Was Found Necessary to Build a New Bridge. Bristol, 1793. Eighteenth Century Collections Online. Web. 30 Jan. 2011.

Politics for the People: Or, a Salmagundi for Swine. London, 1794. Print.

Rogers, Nicholas. The Press Gang: Naval Impressment and Its Opponents in Georgian Britain. London: Continuum, 2007. Print.

Rose, John. An Impartial History of the Late Disturbances in Bristol: Interspersed with Occasional Remarks. To Which Are Added a List of the Killed. Bristol, 1793. Eighteenth Century Collections Online. Web. 3 Feb. 2011.

Shiercliff, Edward. The Bristol and Hotwell Guide. Bristol, 1793. Eighteenth Century Collections Online. Web. 3 Feb. 2011.

Siskin, Clifford. The Work of Writing: Literature and Social Change in Britain, 1700-1830. Baltimore: Johns Hopkins UP, 1998. Print.

Sun [London]. 2 Oct. 1793: 3. 17th-18th Century Burney Collection Newspapers. Web. 30 Jan. 2011.

Sussman, Charlotte. "Women and the Politics of Sugar, 1792." Representations 48 (Autumn, 1994: 48-69. Print.

Thompson, EP. "The Moral Economy of the English Crowd in the Eighteenth Century." Past and Present 50.1 (Feb. 1971): 76-136. Print. 
Todd, Janet. A Dictionary of British and American Women Writers, 1660-1800. Totowa, NJ: Rowman \& Littlefield, 1987. Print.

Voyages: The Trans-Atlantic Slave Trade Database. Emory U, 2009. Web. 1 Jan. $2011<$ http://www.slavevoyages.org>.

Wilson, Kathleen. The Island Race: Englishness, Empire, and Gender in the Eighteenth Century. London: Routledge, 2003. Print.

Winscom, Jane Cave. “An Address to the Inhabitants of Bristol.” Cave, Poems. 1794. 173-80.

—. "Lines Sent to an Examiner in the Excise." Cave, Poems, 1794. 169-72.

—. "On the First General Fast after the Commencement of the late War." Cave, Poems. 1794. 74-78.

—. "On the General Fast, Feb. 8 1782.” Cave, Poems. 1783. 135-37.

—. "A Poem Occasioned by Hearing Prophane Cursing and Swearing." Cave, Poems. 1783. 11617.

-. Poems on Various Subjects, Entertaining, Elegiac, and Religious. Winchester, 1783. Eighteenth Century Collections Online. Web. 3 Feb. 2011.

-. Poems on Various Subjects, Entertaining, Elegiac, and Religious, by Miss Cave, Now Mrs. Winscom. The Fourth Edition, Corrected and Improved, with Many Additional Poems, Never before Published. Bristol, 1794. Eighteenth Century Collections Online. Web. 3 Feb. 2011.

-. Poems on Various Subjects, Entertaining, Elegiac, and Religious, by Miss Cave, Now Mrs. Winscom. Bristol, 1795. Eighteenth Century Collections Online. Web. 3 Feb. 2011.

—. "Thoughts Occasioned by the Proceedings on Bristol-Bridge, and the Melancholy Consequences, on the Awful Night of Monday Last, Being the 30th of September. 1793. (By a Lady.).” Bristol, 1793. Eighteenth Century Collections Online. Web. 30 Jan. 2011.

—. "Thoughts Occasioned by the Proceedings on Bristol-Bridge, and the Melancholy Consequences, on the Awful Night of Monday Last, Being the 30th of September. 1793. (By a Lady.)." Cave. Poems, 1794. 181-87.

—. "Thoughts on the Present Times; Written Some Time after the Proclamation for the Late General Fast.” Cave. Poems, 1795. 197-201.

—. "Written by the Desire of a Lady, on Building of Castles." Cave. Poems, 1783. 57-60. 
The World [London]. 2 Oct 1793: 4. 17th-18th Century Burney Collection Newspapers. Web. 30 Jan. 2011.

The World [London]. 4 Oct. 1793: 3. 17th-18th Century Burney Collection Newspapers. Web. 30 Jan. 2011. 


\section{Notes}

1. This piece benefited from the comments of Madge Dresser, Ryan Smith, Rivka Swenson, Nicholas Woolf, and the other members of Virginia Commonwealth University ${ }^{\text {ee }}$ Eighteenth-Century Studies Reading Group.

2. There has been very little work done on Winscom. She has an entry in the DNB (Grundy). The entry in Janet Todd "s A Dictionary of British and American Women Writers, 1660-1800 laments her "limited poetic powers." Her work has been anthologized in Roger Lonsdale ee sighteenth-Century Women Poets: An Oxford Anthology and Paula R. Backscheider and Catherine Ingrassia ${ }^{\text {ee }}$ s British Women Poets of the Long Eighteenth Century. Winscom suffered debilitating headaches which she discussed in her poetry and that has been the object of some scholarly attention including Elizabeth McKim ${ }^{\text {ee }}$ article, "Making Poetry of Pain: The Headache Poems of Jane Cave Winscom.” Another piece on her Welsh identity has been published, Catherine Messem"s "Irreconcilable Tensions; Gender, Class and the Welsh Question in the Poetry of Jane Cave (c1754-1813).”

3. In her poem, "Lines Sent to an Examiner in the Excise” (1794), Winscom complains about the expense and inconvenience of repeated moves: “And should you stand, soon comes your rout, / For each fourth year you "e moved about” (23).

4. Nicholas Rogers continues: "In Bristol and Liverpool, two of the principal provincial ports in the eighteenth century, the adult male population threatened by impressment was probably a quarter or more, which helps to explain why the subject inflamed the passions of those cities" (8).

5. Rogers also details how those involved in anything related to naval activities (who were of course highly desirable to a press gang) collaborated to further elude and deter press gangs.

6. As Clarkson es report went on to detail, the mortality rate for seamen on slave ships was particularly high. For example, Clarkson notes that Bristol slave ships "have had no accommodations or places of shelter for the seamen, either in sickness or in health" (67). That line of argument - that part of the damage of the slave trade was the effects on the nation "s seamen, the ships being "not a nursery but a graveyard"—was consistently used by the anti-slavery movement.

7. Shiercliff goes on to describe the considerable number of sugar refineries that existed in Bristol and the high quality of their product. "By which means loaf sugar is made here, and sold on better terms than can be done elsewhere, and in general the single refined sugars of Bristol, are held in higher estimation, and will fetch a better price abroad, than that which they receive from other places” (18) He also details the advantages of international trade for Bristoles economy: "merchants have not only the greatest trade, but they trade also with a more intire (sic) independence upon London, than any other 
town in Britain; whatever exportations they make to any part of the world, they are able to bring back the returns to their own port, and can dispose of them there” (14).

8. Harrison suggests, in a departure from the argument of Jones, that associations of this episode with anxiety about the French Revolution "is founded upon the false premise that a riot in 1793 must, somehow, have close links with the impact of the French revolution" (558).

9. Jones goes on to note how this belief provides the "legitimizing notion" E.P. Thompson describes as present in most eighteenth-century riots in his well-known essay, "The Moral Economy of the English Crowd in the Eighteenth Century.”

10. The so-called Riot Act (1 Geo. I. §2, c. 5) was introduced in 1715. The Act made it a felony for an assembly of more than twelve people to refuse to disperse within one hour of being ordered to do so and having been read a specified portion of the Act by lawful authority, and provided that after this hour the assembly could be dispersed by force. To read the Riot Act, one would recite the following: "Our Sovereign Lord the King chargeth and commandeth all persons, being assembled, immediately to disperse themselves, and peaceably to depart to their habitations, or to their lawful business, upon the pains contained in the act made in the first year of King George, for preventing tumults and riotous assemblies. God Save the King!”

11. Except where otherwise indicated, this account of the events at the Bristol Bridge is taken primarily from the previously cited, John Rose, An Impartial History of the Late Disturbances in Bristol (1793).

12. Or “A Poem, Occasioned by Hearing Prophane Cursing and Swearing” finds the use of profanity cause for divine vengeance:

And can we wonder, if the sword

Is plung ${ }^{\text {ed }}$ in Brothers blood?

If threat "ening vengeance flies around

From a tremendous God. (1-4)

13. In the 1794 edition of Poems on Various Subjects, the poem "e s title added the phrase "Written During the American War."

14. Jane Cave ees first volume of poetry, Poems on Various Subjects, Entertaining, Elegiac, and Religious, was published by subscription in Winchester in 1783. In 1786, Poems on Various Subjects, Entertaining, Elegiac, and Religious. With a Few Select Poems from Other Authors. By Miss Cave. Now Mrs. W-- was published in Bristol "for the author" with additional subscribers. A second edition was published in 1789 in Shrewsbury. The 1794 edition was described on the title page as "The Fourth Edition, Corrected and Improved, with Many Additional Poems, Never before Published.” It was published in Bristol by N. Biggs. It asserts that the "great Number of Nobility and other respectable Persons who subscribed to the former Editions of this Work, it is presumed, will be a sufficient Recommendation to every future Purchaser” (A3). It then provides a select list 
of the "more than Fifteen Hundred" previous subscribers. Throughout her writing, Winscom also presents local "calamities" as a kind of divine retribution. "Do not a nation"s sad offences call / For national calamities to fall?" (17-18) she asks in "On the First General Fast after the Commencement of the late War."

15. Winscom specifically places these scenes of torture on the streets, suggesting again that she is alluding both to public beatings of slave or also the public display of governmental control with the shootings at the Bristol Bridge.

16. To make matters even more complicated, and cause potential confusion in the chain of command," details Michael Manson, "the militia were under the order not of their own officers, but of the local magistrates.” (49).

17. There are numerous examples of the military exacting punishment in this way. For example, The History of the Rebellion in 1745 and 1746 details how Maiben, a journeyman apprentice to a wigmaker, was "stripped, tied to halberts in the market place, and whipped" for making disparaging comments about a military officer. Francis Douglas, The History of the Rebellion in 1745 and 1746, Extracted from the Scots Magazine: With an Appendix (261). A 1794 collection, Politics for the People: Or, a Salmagundi for Swine, details how, for stealing two eggs "The poor volunteer to the halberts is tied," and flogged until "the blood gushes down from his nape to his heels" (173). 